\title{
Relationship between glycemic metabolism and hypothyroidism in patients with type 2 diabetes mellitus
}

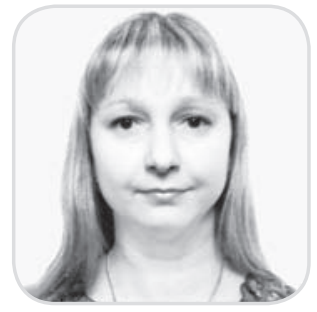

\section{T. Yu. Yuzvenko ' , V. I. Pankiv ${ }^{1}$, K. Singh ${ }^{1}$, Chandanvir Saini ${ }^{2}$}

${ }^{1}$ Ukrainian Research and Practical Centre of Endocrine Surgery, Transplantation of Endocrine Organs and Tissues of the Ministry of Health of Ukraine, Kyiv, Ukraine

${ }^{2}$ Warrnambool Medical Clinic, Lyndoch, Australia

\section{INTRODUCTION}

Recent decades have been characterized by a significant increase in the incidence of endocrine system diseases and polyendocrinopathies. Combination of diabetes mellitus (DM) and hypothyroidism has been widely reported to be more common [1].

Pandemic of type 2 DM, significant increase in the incidence of obesity and autoimmune diseases are important medical and social problem of modern society. The prevalence of overt hypothyroidism according to various epidemiological studies is from 0.2 to $4 \%$, subclinical hypothyroidism - up to 7.0 $9.5 \%[2,3]$. Incidence of hypothyroidism in patients with DM is higher than in the general population, and is according to various authors $6.9-31.4 \%$ [4]. It is known that the presence of concomitant hypothyroidism worsens the lipid spectrum, contributing to the progression of vascular diabetes complications [5].

There are a number of problems associated with the presence of combined pathology with chronic diseases in the treatment of patients with type $2 \mathrm{DM}$. This combination of type $2 \mathrm{DM}$ and hypothyroidism is characterized by age selectivity [6]. Type $2 \mathrm{DM}$ and hypothyroidism are more common in older women, due to decreased of sex hormones, cytotoxic lymphocyte activity and increased sensitivity to autoimmune factors [7]. In the group of middle-aged and older women, the prevalence of all forms of hypothyroidism reachs $12 \%$ [8]. These data suggest that hypothyroidism is one of the most common endocrine diseases among the elderly.

Nowadays, studies have been published to assess the prevalence of thyroid dysfunction in patients with type 2 DM. But all these studies differ in design and are conducted in different ethnic groups. All researchers came to general conclusion: the prevalence of hypothyroidism in patients with type $2 \mathrm{DM}$ is significantly higher than in the general population [9].

Increasing the frequency of combination of type 2 DM with hypothyroidism affects the features of the clinical course of such pathology, remains an important problem of modern medical science. However, in the literature there are isolated data on the mutual influence on the clinical course of combined pathology containing type $2 \mathrm{DM}$ and hypothyroidism [10].

A feature of the clinical development of type 2 DM is a long asymptomatic course of the disease. Type $2 \mathrm{DM}$ is detected when the patient is under observation of cardiologist or when providing emergency medical

Юзвенко Тетяна Юріївна, д. мед. н., професор, заступник директора. 01021, м. Київ, Кловський узвіз, 13-А; Тел. (044) 254-32-23. E-mail: tatyuzvenko@gmail.com; 0RCID: http://orcid.org/00000003-4229-2075; Паньків Володимир Іванович, д. мед. н., професор, завідувач відділу профілактики, лікування цукрового діабету та його ускладнень, Заслужений лікар України. 01021, м. Київ, Кловський узвіз, 13-A. Тел. (044) 254-30-91. E-mail: endocr@i.ua. ORCID: http://orcid.org/0000-0002-9205-9530; Сінгх Канварджіт, лікар-ендокринолог, зав. консультативної поліклініки; Сhаndanvir Saini, MD, GP, MBBS, FRACGP, Warnrnambool Medical Clinic, Lyndoch, Warrnambool 3280, VIC, Australia. ORCID: http://orcid.org/0000-0003-3077-339X. 
care in hospital. Prolonged asymptomatic course of DM leads to the fact that more than $50 \%$ of patients at the time of diagnosis already have various complications [11].

In recent years, there are a lot of subclinical forms of thyroid pathology on the background of type $2 \mathrm{DM}$, in which the clinical manifestations of hypothyroidism may be indistinct, and in the first place are signs of carbohydrate metabolism disorders [12]. It is known that even a slight violation of the content of thyroid hormones exacerbates the pathology of the cardiovascular system, especially in type 2 DM [13].

Thus, due to the difficulty of diagnosing hypothyroidism in asymptomatic or atypical course in patients with type $2 \mathrm{DM}$, as both diseases have similar symptoms, this problem is actual. Taken to attention high prevalence of type $2 \mathrm{DM}$ and hypothyroidism in the population, the study of the relationship between these diseases is relevant to improve the diagnosis and treatment.

The work was performed in accordance with the research plan of the Ukrainian Research and Practice Center for Endocrine Surgery, Transplantation of Endocrine Organs and Tissues of the Ministry of Health of Ukraine and is a fragment of scientific investigation «Optimization of prevention, diagnosis and treatment of diabetes mellitus on the background of comorbid pathology with iodine and vitamin $D$ deficiency» (state registration 0113U006386).

The aim of this study was to analyze the frequency of hypothyroidism in patients with type 2 diabetes mellitus and to establish the clinical features of type 2 diabetes mellitus in combination with hypothyroidism.

\section{MATERIALS AND METHODS}

The work was performed on the basis of the Department of Prevention and Treatment of Diabetes of the Ukrainian Scientific and Practical Center for Endocrine Surgery, Transplantation of Endocrine Organs and Tissues of the Ministry of Health of Ukraine.

We examined 181 patients with DM in combination with primary hypothyroidism, including 65 patients with type $1 \mathrm{DM}$ and 116 patients with type $2 \mathrm{DM}$. The comparison groups consisted of 64 patients with DM without hypothyroidism (28 of them - with type 1 DM, 36 - with type 2 DM).

The duration of DM and hypothyroidism was assessed according to the history of life and disease, as well as according to outpatient medical histories of patients. Diagnosis of DM was made according to the criteria of the World Health Organization (1999). Assessment of the thyroid functional state was performed according to clinical data and hormonal examination data.

Patients with type 2 DM and hypothyroidism belonged to an older age category than patients with type $1 \mathrm{DM}$ and hypothyroidism. Thus, the age of patients in the group of patients with type $1 \mathrm{DM}$ with hypothyroidism ranged from 23.1 to 47.8 years (average age $-35.4 \pm 9.6$ ) and in the group of patients with type 2 DM with hypothyroidism - from 37.5 to 59.3 years (average age $-47.8 \pm 11.4$ ). The duration of DM in these two groups of examined patients was approximately the same and ranged from 8.4 to 17.1 years (average duration of type $1 \mathrm{DM}-11.7 \pm$ 3.4 years and type $2 \mathrm{DM}-13.6 \pm 2.8$ years, accordingly).

The distribution by gender was as follows: among patients with type $2 \mathrm{DM}$ in combination with hypothyroidism, there were 27 men $(22.7 \%)$ and 90 women $(77.3 \%)$; among patients with type $1 \mathrm{DM}$ in combination with hypothyroidism - 24 (36.0\%) men and 42 (64.0\%) women.

In all groups of patients, the percentage of women was significantly higher than men, which confirms the literature on the higher incidence of hypothyroidism in women and is associated with age-related changes in hormonal expression (estrogen, progesterone), against which develop autoimmune disorders [14].

All patients recorded passport data, complaints, life history and disease. We investigated anthropometric data (weight and height at the time of initial examination, body mass index (BMI)), objective study data, examination of other specialists (ophthalmologist, neurologist, cardiologist), prescribed treatment, as well as the dynamics of clinical symptoms and laboratory tests.

The thyroid functional state was assessed by determining the basal concentrations of thyroidstimulating hormone (TSH) and free thyroxine (fT4) in the serum by enzyme-linked immunosorbent assay using reagents from DRG (Germany) on an automatic analyzer iEMS Reader MF from ThermoLabsystems (Finland). Normal TSH values corresponded to $0.23-4.0 \mu \mathrm{lU} / \mathrm{ml}$.

A study of carbohydrate metabolism (fasting and postprandial glycemia, glycated hemoglobin ( $\mathrm{HbA} 1 \mathrm{c})$ ), lipid metabolism - total cholesterol, low-density lipoprotein (LDL) cholesterol, high-density lipoprotein (HDL) cholesterol.

Statistical analysis contained descriptive statistics, checking the nature of the indicators distribution. 
Clinical characteristics of the examined patients with diabetes mellitus $(M \pm m)$

\begin{tabular}{|l|l|l|l|l|}
\hline \multirow{2}{*}{ Indicators } & \multicolumn{3}{|c|}{ Group and number of respondents } \\
\cline { 2 - 5 } & Type 1 DM, $\mathbf{n = 2 8}$ & Type 2 DM, $\mathbf{n = 3 6}$ & $\begin{array}{l}\text { Type 1 DM and } \\
\text { hypothyroidism, } \\
\mathbf{n = 6 5}\end{array}$ & $\begin{array}{l}\text { Type 2 DM and } \\
\text { hypothyroidism, } \\
\mathbf{n}=116\end{array}$ \\
\hline Age, years & $31.5 \pm 9.3$ & $51.8 \pm 9.2^{*}$ & $35.4 \pm 9.6$ & $47.8 \pm 11.4^{* *}$ \\
\hline Duration of hypothyroidism, years & $6.8 \pm 1.2$ & $4.8 \pm 0.8$ & $8.1 \pm 0.9$ & $5.4 \pm 1.5$ \\
\hline DM duration, years & $10.7 \pm 2.1$ & $11.9 \pm 2.3$ & $11.7 \pm 3.4$ & $13.6 \pm 2.8$ \\
\hline BMl, $\mathrm{kg} / \mathrm{m}^{2}$ & $23.6 \pm 0.7$ & $32.7 \pm 0.6^{*}$ & $26.4 \pm 0.8$ & $33.1 \pm 0.8^{* *}$ \\
\hline TG, $\mathrm{mM} / \mathrm{l}$ & $1.6 \pm 0.3$ & $2.3 \pm 0.8^{*}$ & $1.9 \pm 0.3$ & $2.8 \pm 0.9^{* *}$ \\
\hline Total cholesterol, $\mathrm{mM} / \mathrm{l}$ & $5.4 \pm 0.3$ & $6.8 \pm 0.4^{*}$ & $5.7 \pm 0.4$ & $7.2 \pm 0.4^{* *}$ \\
\hline $\mathrm{HbA} 1 \mathrm{c}, \%$ & $8.9 \pm 0.4$ & $7.8 \pm 0.3$ & $8.4 \pm 0.2$ & $8.3 \pm 0.3$ \\
\hline
\end{tabular}

Notes: * significance of differences between groups of patients with type 2 DM and type 1 DM according to Student's t-test $(p<0,05)$; ** significance of differences between groups of patients with type 2 DM with hypothyroidism and type 1 DM with hypothyroidism according to Student's t-test $(\mathrm{p}<0.05) ; \mathrm{TG}$ — triglycerides

Significance of differences was assessed by Student's t-test ( $t$ ) for normal distribution. Differences with a confidence level of less than 0.05 were considered clinically significant. All statistical calculations were performed at a significance level of $95 \%(p=0.05)$. If there was a distribution other than normal, nonparametric calculation method was used - the Mann-Whitney U-test for two independent samples. The obtained data in the tables and text are presented as relative values (\%), as well as ( $M \pm m$ ), where $M$ is the arithmetic mean, $\mathrm{m}$ is the standard error of the mean, Me $[25 ; 75]$, where $\mathrm{Me}$ is median, 25th and 75th quartiles. The differences were considered statistically significant at $p<0.05$.

Ethical approval for the study was obtained from the Ukrainian Research and Practical Centre of Endocrine Surgery, Transplantation of Endocrine Organs and Tissues of the Ministry of Health of Ukraine Ethics Committee (protocol No. 8; 29.11.2018). All participants were briefed about the study and gave informed written consent to participate.

\section{RESULTS}

It was found that in patients with DM and on the background of concomitant pathology, carbohydrate metabolism was not in a state of compensation during the study (Table 1).

We analyzed the state of carbohydrates metabolism in patients with type 1 and type $2 \mathrm{DM}$ in combination with hypothyroidism. There were significant differences in the rate of glycemia, namely, its increase in patients with type $1 \mathrm{DM}$ with hypothyroidism (deviation of glycemia during the day was $6.2 \pm 0.8 \mathrm{mM} / \mathrm{l}$ ). Higher glycemic amplitude may indicate more significant fluctuations in glucose level, and, consequently, a more labile course of type 1 DM associated with hypothyroidism.

Table 2 shows the analysis of gender indicators of lipid metabolism in patients with type 1 and type 2 DM with hypothyroidism.

The obtained results indicate the absence of gender differences in triglyceride levels in patients with type 1 and type $2 \mathrm{DM}$ with hypothyroidism. But in the group of patients with type $2 \mathrm{DM}$ with hypothyroidism, the rates of total cholesterol are significantly higher ( $p<$ 0.05) than in patients with type 1 DM with hypothyroidism.

Patients with type $2 \mathrm{DM}$ were older than patients with type $1 \mathrm{DM}$, they had abdominal obesity and elevated levels of total cholesterol and TG compared with patients with type $1 \mathrm{DM}$. Immune system with age undergoes functional changes, which should be taken into account when studying the effect of metabolic parameters in patients with type $2 \mathrm{DM}$. It should be emphasized that in the combination of type $2 \mathrm{DM}$ with hypothyroidism, disorders of lipid metabolism were impressive than in type 2 DM without thyroid pathology. This confirms the effect of hypothyroidism on lipid metabolism and increases the risk of progression of cardiovascular complications in the presence of two diseases.

Type 2 DM and hypothyroidism, according to our data, are more common in women. Hypothyroidism 
Indicators of lipid metabolism in patients with type 1 and type 2 diabetes mellitus in combination with hypothyroidism depending on gender $(\mathrm{M} \pm \mathrm{m})$

\begin{tabular}{|l|l|l|l|l|l|l|}
\hline \multirow{2}{*}{ Indicators } & \multicolumn{5}{|c|}{ Group and number of respondents } \\
\cline { 2 - 7 } & \multicolumn{3}{|c|}{ Type 1 DM and hypothyroidism } & \multicolumn{2}{c|}{ Type 2 DM and hypothyroidism } \\
\cline { 2 - 7 } & Women, $\mathbf{n = 4 2}$ & Men, $\mathbf{n = 2 3}$ & Total, $\mathbf{n = 6 5}$ & Women, $\mathbf{n = 9 0}$ & Men, $\mathbf{n = 2 6}$ & $\begin{array}{l}\text { Total, } \\
\mathbf{n}=116\end{array}$ \\
\hline $\begin{array}{l}\text { Total cholesterol, } \\
\mathrm{mM} / \mathrm{I}\end{array}$ & $5.9 \pm 0.4$ & $5.3 \pm 0.3$ & $5.7 \pm 0.4$ & $7.4 \pm 0.5$ & $7.1 \pm 0.7$ & $7.3 \pm 0.3^{*}$ \\
\hline $\mathrm{TG}, \mathrm{mM} / \mathrm{l}$ & $1.6 \pm 0.2$ & $1.8 \pm 0.3$ & $1.7 \pm 0.3$ & $2.9 \pm 0.8$ & $2.7 \pm 0.6$ & $2.8 \pm 0.7$ \\
\hline
\end{tabular}

Note: * the significance of differences between groups of patients with type 1 DM with hypothyroidism and type 2 DM with hypothyroidism according to Student's t-test.

was also significantly more common in patients with type 2 DM.

\section{DISCUSSION}

According to the results of a retrospective analysis of selected patients number with combined endocrine pathology in the form of DM and hypothyroidism, it was found that among the examined patients hypothyroidism occurred 2.5 times more often in type 2 DM than in type $1 \mathrm{DM}$. It indicates a greater presence of risk factors for the development of concomitant autoimmune pathology in conditions of metabolic disorders in type $2 \mathrm{DM}$. It was found that in patients with type 2 DM with concomitant hypothyroidism, diffuse changes and nodules in the structure of thyroid tissue were much more common. The above facts suggest that insulin resistance and hyperinsulinemia, which are observed in type $2 \mathrm{DM}$, contribute to proliferative processes, including in thyroid tissue, and older age of patients with type 2 DM contributes to the progression of involutional changes and further development of thyroid hypofunction.

All patients were in a state of DM sub- and decompensation, it should also be noted that in type 2 DM there were more pronounced changes in lipid metabolism (levels of total cholesterol, TG) were significantly higher than in type $1 \mathrm{DM}$. It is known that metabolic disorders enhance the formation of free radical nitric oxide, which is involved in destructive apoptosis of cells during the start and prolongation of autoimmune aggression [15].

It should be noted that patients with type 2 DM belonged to an older age group, so it is necessary to take into account the age. It is known that in old age there is selective decrease in the function of one of the subpopulations of lymphocytes while maintaining another function [16]. Thus, with aging, imbalance of T-cell and cytokines develops, which is manifested by a deficiency of T-suppressors/cytotoxic drugs and increased levels of leptin and IL-6. Under conditions of more pronounced metabolic disorders in type $2 \mathrm{DM}$, as well as taking into account age-related changes in the immune system, patients with type 2 DM have significant risk factors for autoimmune processes [17].

Combination of type 2 DM with hypothyroidism is quite common thanks to high prevalence of DM as well as autoimmune diseases in the last decade in the population, and the trend of population aging in the world. It is also important that the mechanisms involved in organ and tissue damage in patients with type $2 \mathrm{DM}$ are quite complex, but they are based on both metabolic and immunological changes [18]. Under conditions of hyperglycemia, many factors are activated that normally regulate tissue homeostasis. It should be emphasized that these disorders are not specific to DM, as they are often found in a variety of inflammatory and degenerative lesions [19]. In patients with DM, these disorders are complicated by hyperglycemia, as well as other biochemical disorders that occur against its background. The importance of hyperglycemia as one of the risk factors for the development of autoimmune disorders in patients with DM has been shown in many studies that have shown that maintaining strict metabolic control can normalize immunological changes $[20,21]$.

As a result of this work, a mandatory comprehensive examination of patients with type $2 \mathrm{DM}$ is recommended for the presence of concomitant thyroid pathology.

\section{CONCLUSIONS}

1. Patients with type 2 diabetes mellitus and hypothyroidism belong to an older age category than 
patients with type 1 diabetes mellitus and hypothyroidism.

2. Significant differences in glycemic amplitude were found, namely, its increase in patients with type 1 diabetes mellitus with hypothyroidism. This indicates more significant fluctuations in glucose content, and, consequently, a more labile course of type 1 diabetes mellitus, combined with hypothyroidism.

3. In the combination of type 2 diabetes mellitus with hypothyroidism, lipid metabolism was higher than in type 2 diabetes mellitus without thyroid pathology. This confirms the effect of hypothyroidism on lipid metabolism and increases the risk of progression of cardiovascular complications in the presence of two diseases.

Institution, which financed the research: Ukrainian Research and Practical Centre of Endocrine Surgery, Transplantation of Endocrine Organs and Tissues of the Ministry of Health of Ukraine, Kyiv, Ukraine.

The authors assume responsibility for the published work. The authors guarantee absence of competing interests and their own financial interest when carrying out the research and writing the article.

участь авторів. Обстеження/підбір хворих T.Ю.Юзвенко; концепція і дизайн дослідження В.І. Паньків; обстеження/підбір хворих - К. Сінгх; написання тексту, редагування - Chandanvir Saini.

\section{REFERENCES}

1. Ogbonna SU, Ezeani IU, Okafor $\mathrm{Cl}$, Chinenye S. Association between glycemic status and thyroid dysfunction in patients with type 2 diabetes mellitus. Diabetes Metab Syndr Obes. 2019;12:1113-22. doi: 10.2147/DMSO.S204836.

2. Ogbonna SU, Ezeani IU. Risk factors of thyroid dysfunction in patients with type 2 diabetes mellitus. Front Endocrinol (Lausanne). 2019;10:440. doi: 10.3389/ fendo.2019.00440.

3. Han C, He X, Xia X. et al. Subclinical hypothyroidism and type 2 diabetes: a systematic review and meta-analysis. PLoS One. 2015;10(8):e0135233. doi: 10.1371/journal. pone.0135233. eCollection 2015.

4. Ashrafuzzaman SM, Taib AN, Rahman R, Latif ZA. Prevalence of diabetes among hypothyroid subjects. Mymensingh Med J. 2012;21 (1):129-32. PMID: 22314468.

5. Fleiner HF, Bjøro T, Midthjell K, Grill V, Åsvold BO. Prevalence of thyroid dysfunction in autoimmune and type 2 diabetes. The population-based HUNT Study in Norway. J Clin Endocrinol Metab. 2015:jc20153235. DOI: 10.1210/jc.2015-3235.
6. Surks MI, Ortiz E, Daniels GH. et al. Subclinical thyroid disease: scientific review and guidelines for diagnosis and management. JAMA. 2004;291(2):228-38. doi: 10.1001/jama.291.2.228291/2/228 [pii].

7. Nishi M. Diabetes mellitus and thyroid diseases. Diabetol Int. 2018;9(2):108-12. doi: 10.1007/s13340-018-0352-4.

8. Distiller LA, Polakow ES, Joffe BI. Type 2 diabetes mellitus and hypothyroidism: the possible influence of metformin therapy. Diabet Med. 2014;31(2):172-5. doi: 10.1111/ dme.12342.

9. Pearce SH, Brabant G, Duntas LH. et al. 2013 ETA Guideline: Management of Subclinical Hypothyroidism. Eur Thyroid J. 2013;2(4):215-28. doi:10.1159/000356507 etj-0002-0215 [pii].

10. Garber JR, Cobin RH, Gharib H. et al. Clinical practice guidelines for hypothyroidism in adults: cosponsored by the American Association of Clinical Endocrinologists and the American Thyroid Association. Thyroid. 2012;22(12):1200-35. doi:10.1089/thy.2012.0205 .

11.Zhao W, Han C, Shi X. et al. Prevalence of goiter and thyroid nodules before and after implementation of the universal salt iodization program in mainland China from 1985 to 2014: a systematic review and metaanalysis. PLoS One. 2014;9(10):e109549 doi:10.1371/ journal.pone.0109549 PONE-D-14-20444 [pii].

12. Diez JJ, Sanchez P, Iglesias P. Prevalence of thyroid dysfunction in patients with type 2 diabetes. Exp Clin Endocrinol Diabetes. 2011;119(4):201-7. doi: 10.1055/s-0031-1271691.

13. Chaker L, Ligthart S, Korevaar TIM. et al. Thyroid function and risk of type 2 diabetes: a population-based prospective cohort study. BMC Med. 2016;14:150-7. doi: 10.1186/s12916-016-0693-4.

14. Duntas LH, Orgiazzi J, Brabant G. The interface between thyroid and diabetes mellitus. Clin Endocrinol. 2011;75:19. doi: 10.1111/j.1365-2265.2011.04029.x.

15. Lambadiari V, Mitrou P, Maratou E. et al. Thyroid hormones are positively associated with insulin resistance early in the development of type 2 diabetes. Endocrine. 2011;39:28-32. doi: 10.1007/s12020-010-9408-3.

16. Joffe BI, Distiller LA. Diabetes mellitus and hypothyroidism: strange bedfellows or mutual companions? World J Diabetes. 2014;5:901-4. doi: 10.4239/wjd.v5.6.901.

17. Pankiv VI, Yuzvenko TYu, Pankiv IV. Type 2 diabetes mellitus and subclinical hypothyroidism: focusing on the role of cholecalciferol. Problems of Endocrine Pathology. 2019;2:46-51. Doi 10.21856/j-PEP.2019.2.07.

18. Goncharova OA, Arkhipkina TL, Bondarenko VO, Lyubimova LP. Vitamin D status and features of the 
immune status in women with autoimmune thyroiditis in the postmenopausal period. Clinical Endocrinology and Endocrine Surgery. 2020;1(69):51-6. DOl: http://doi. org/10.30978/CEES-2020-1-51.

19. Koga M, Murai J, Saito H, Matsumoto S, Kasayama S. Effects of thyroid hormone on serum glycated albumin levels: study on non-diabetic subjects. Diabetes Res Clin Pract. 2009;84:163-7.doi: 10.1016/j.diabres.2009.01.013.

20. Krytskyi TI, Pasiechko NV. Correlation of hypothyroidism and androgen deficiency in men of different periods of mature age. Mižnarodnij endokrinologičnij žurnal. 2018;14(1):35-9. doi: 10.22141/2224-0721.14.1.2018.127089

21. Papazafiropoulou A, Sotiropoulos A, Kokolaki A. et al. Prevalence of thyroid dysfunction among Greek type 2 diabetic patients. J Clin Med Res. 2010;2:75-8. doi:10.4021/jocmr2010.03.281w.

\section{ABSTRACT}

\section{Relationship between glycemic metabolism and hypothyroidism in patients with type 2 diabetes mellitus}

\section{T. Yu. Yuzvenko ', V. I. Pankiv ', K. Singh ', Chandanvir Saini ${ }^{2}$}

${ }^{1}$ Ukrainian Research and Practical Centre of Endocrine Surgery, Transplantation

of Endocrine Organs and Tissues of the Ministry of Health of Ukraine, Kyiv, Ukraine

${ }^{2}$ Warrnambool Medical Clinic, Lyndoch, Australia

The purpose of the work is to study the prevalence of hypothyroidism in patients with type 2 diabetes mellitus and to establish the clinical features of type 2 diabetes in combination with hypothyroidism.

Materials and methods. Examination of 181 patients with diabetes in combination with primary hypothyroidism was performed, of which 65 with type 1 diabetes and 116 with type 2 diabetes. The comparison groups consisted of 64 patients with diabetes without hypothyroidism, including 28 with type 1 diabetes, 36 with type 2 diabetes. The functional state of the thyroid gland was assessed by determining the basal concentrations of thyroid-stimulating hormone and the free thyroxine.

Results and discussion. Patients with type 2 diabetes and hypothyroidism had belonged to an older age group than patients with type 1 diabetes and hypothyroidism (mean age was ( $47.8 \pm 11.4$ ) and (35.4 \pm 9.6$)$ respectively). In all groups of patients the proportion of women significantly exceeded that of men. There were statistically significant differences in the degree of glycemia, namely, an increase in patients with type 1 diabetes with hypothy- roidism. In the case of combination of type 2 diabetes with hypothyroidism, lipid metabolism was higher than in type 2 diabetes without thyroid pathology. This confirms the effect of hypothyroidism on lipid metabolism and lead to increased risk of progression of cardiovascular complications in the presence of two diseases.

Conclusions. Among the examined patients, hypothyroidism occurred 2.5 times more often in type 2 diabetes compared to type 1 diabetes, which indicates a greater presence of risk factors for concomitant autoimmune pathology in metabolic disorders associated with type 2 diabetes. Mandatory comprehensive examination of patients with type 2 diabetes for concomitant thyroid pathology is recommended.

Key words: diabetes mellitus, hypothyroidism, prevalence.

\section{PEЗЮME}

\section{Взаємозв'язок між показниками вуглеводного обміну та гіпотиреозом у хворих на цукровий діабет 2 типу}

\section{Т. Ю. Юзвенко ${ }^{1}$, В. І.Паньків ${ }^{1}$, К. Сінгх ${ }^{1}$, Chandanvir Saini ${ }^{2}$}

\author{
' Український науково-практичний чентр ендокринної \\ хірургії, трансплантації ендокринних органів і тканин \\ мОЗ України, м. Київ, Україна \\ ${ }^{2}$ Warrnambool Medical Clinic, Lyndoch, Australia
}

Мета роботи - вивчити частоту гіпотиреозу у хворих на цукровий діабет (ЦД) 2 типу та встановити клінічні особливості перебігу ЦД 2 типу в поєднанні з гіпотиреозом.

Матеріали та методи. Проведено обстеження 181 пацієнта із ЦД у поєднанні з первинним гіпотиреозом, 3 них 65 із ЦД 1 типу і 116 із ЦД 2 типу. Групи порівняння утворили 64 хворих на ЦД без гіпотиреозу, з них 28 з ЦД 1 типу, 36 із ЦД 2 типу. Функціональний стан щитоподібної залози оцінювали за допомогою визначення базальних концентрацій тиреотропного гормону і вільної фракції тироксину.

Результати та обговорення. Пацієнти із ЦД 2 типу та гіпотиреозом належали до старшої вікової категорії, порівняно з пацієнтами з ЦД 1 типу і гіпотиреозом (середній вік становив $(47,8 \pm 11,4)$ та $(35,4 \pm 9,6)$ року відповідно). В усіх групах хворих частка жінок значно перевищувала частку чоловіків. Виявлено статистично значущі відмінності щодо амплітуди глікемії, а саме, їі збільшення у хворих на ЦД 1 типу з гіпотиреозом. При поєднанні ЦД 2 типу з гіпотиреозом показники ліпідного обміну були вищими, ніж при ЦД 
2 типу без тиреоїдної патології. Це підтверджує вплив гіпотиреозу на ліпідний обмін та зумовлює підвищення ризику прогресування серцево-судинних ускладнень за наявності двох захворювань.

Висновки. Серед обстежених хворих гіпотиреоз траплявся в 2,5 разу частіше при ЦД 2 типу порівняно з ЦД 1 типу, що свідчить про більшу наявність чинників ризику розвитку супутньої автоімунної патології за умов метаболічних порушень при ЦД 2 типу. Рекомендовано обов'язкове комплексне обстеження хворих на ЦД 2 типу щодо наявності супутньої тиреоїдної патології.

Ключові слова: цукровий діабет, гіпотиреоз, поширеність.

\section{PЕЗЮME}

Взаимосвязь между показателями углеводного обмена и гипотиреозом у больных с сахарным диабетом 2 типа

\section{Т. Ю. Юзвенко ', В. И. Панькив ${ }^{1}$, К. Сингх ${ }^{1}$, Chandanvir Saini ${ }^{2}$}

${ }^{1}$ Украинский научно-практический центр эндокринной хирургии, трансплантации эндокринных органов и тканей МЗ Украины, Киев, Украина

${ }^{2}$ Warrnambool Medical Clinic, Lyndoch, Australia

Цель работы - изучить частоту гипотиреоза у больных с сахарным диабетом (СД) 2 типа и установить клинические особенности течения СД 2 типа в сочетании с гипотиреозом.

Материалы и методы. Проведено обследование 181 пациента с СД в сочетании с первичным гипотиреозом, из них 65 с СД 1 типа и 116 с СД 2 типа.
Группы сравнения образовали 64 больных с СД без гипотиреоза, из них 28 с СД 1 типа, 36 с СД 2 типа. Функциональное состояние щитовидной железы оценивали с помощью определения базальных концентраций тиреотропного гормона и свободной фракции тироксина.

Результаты и обсуждение. Пациенты с СД 2 типа и гипотиреозом принадлежали к старшей возрастной категории, по сравнению с пациентами с СД 1 типа и гипотиреозом (средний возраст составлял $(47,8 \pm 11,4)$ и $(35,4 \pm 9,6)$ года соответственно). Во всех группах больных доля женщин значительно превышала долю мужчин. Выявлены статистически значимые различия по амплитуде гликемии, а именно, ее увеличение у больных с СД 1 типа с гипотиреозом. При сочетании СД 2 типа с гипотиреозом показатели липидного обмена были выше, чем при СД 2 типа без тиреоидной патологии. Это подтверждает влияние гипотиреоза на липидный обмен и обуславливает повышение риска прогрессирования сердечно-сосудистых осложнений при наличии двух заболеваний.

Выводы. Среди обследованных больных гипотиреоз встречался в 2,5 раза чаще при СД 2 типа по сравнению с СД 1 типа, что свидетельствует о большем наличии факторов риска развития сопутствующей аутоиммунной патологии в условиях метаболических нарушений при СД 2 типа. Рекомендовано обязательное комплексное обследование больных сСД 2 типа на предмет наличия сопутствующей тиреоидной патологии.

Ключевые слова: сахарный диабет, гипотиреоз, распространенность.

Дата надходження до редакції 03.10.2020 p. 